\title{
Essay
}

\section{How the Obama Administration Should Regulate the Financial Sector}

\author{
Michael S. Solender ${ }^{\dagger}$
}

The Obama Administration will be looking to the financial regulatory apparatus to prevent future economic crises like the one the country is experiencing right now. Any ungainly financial "Departments of Homeland Security" created as part of the Administration's reform agenda that lack key regulatory attributes will not play an effective role in preventing or mitigating future financial crises. Whatever their final form, the ultimate financial regulators need the right people, adequate access and information, the ability to analyze that information, and a means to respond rapidly to financial emergencies. Otherwise they will have little hope of doing the proactive, forward-looking thinking the Administration will need them to perform.

\section{Introduction}

The Obama Administration will be looking to the financial regulatory apparatus to prevent future economic crises like the one the country is experiencing right now. This is a very ambitious objective to impose on any regulator. Much ink has been spilled in addressing how the financial regulatory apparatus should be constructed going forward. The focus has been on consolidating the multiple agencies with overlapping jurisdictions that oversee the financial-services industry. ${ }^{1}$ Whatever their final form, we can identify

\footnotetext{
† Michael S. Solender is a Visiting Lecturer in Law at the Yale Law School and has served as a senior executive in the financial-services industry.

1 See, e.g., Financial Regulation: A Framework for Crafting and Assessing Proposals To Modernize the Outdated U.S. Financial Regulatory System: Hearing Before the Cong. Oversight Panel, (Jan. 14, 2009) at 13, http://www.gao.gov/new.items/d09310t.pdf [hereinafter GAO Testimony] ("Having a single entity responsible for assessing threats to the overall financial system could prevent some of the crises that we have seen in the past."); THE DEP'T OF THE TREASURY, BLUEPRINT FOR A MODERNIZED FINANCIAL REgULATORY STRUCTURE 137-38 (2009), available at $\mathrm{http}: / / \mathrm{www} . u s t r e a s . g o v / p r e s s /$ releases/reports/Blueprint.pdf (proposing the creation of three regulators for the financial sector: a market stability regulator, a prudential financial regulator to focus on financial institutions with some type of explicit government guarantees, and a business conduct regulator); GROUP OF THIRTY, FINANCIAL REFORM: A FRAMEWORK FOR FINANCIAL STABILITY 28 (2008) [hereinafter G30 REPORT], available at http://www.scribd.com/doc/11358851/Group-of-Thirty-Financial-ReformAFramework-for-Financial-Stability ("[T]he activities of government-insured, deposit-taking institutions should be subject to prudential regulation and supervision by a single regulator (that is, consolidated
} 
certain key attributes these ultimate financial regulators should have to give them at least some hope of doing the proactive, forward-looking thinking the Administration will need them to perform: the right people at the agencies, enough access to the institutions they regulate, enough information from those institutions to know what is happening, an internal brain trust to analyze and assess that information, and a rapid reaction team to respond to financial emergencies.

\section{The Right People}

The regulatory agencies must have the right personnel, including not only experienced regulators, but also financial professionals with inside knowledge of business and the markets. The agencies typically recruit people at early stages of their careers, and while these recruits often bring energy, enthusiasm, and intelligence, they do not typically have a deep understanding of the financial sector. The failure or inability to hire more people with industry experience has been attributed to obstacles such as the disparity between government and private sector compensation, as well as the cumbersomeness of the government hiring process-obstacles that, at least right now, should be surmountable.

Regulators themselves have recognized the value of having employees with real industry experience. For example, the Executive Director of the Securities and Exchange Commission (SEC) testified in 2003 that, with respect to regulatory examiners, "[o]ften, the best candidates ... are those with industry experience. ... There is no substitute for having been on the other side of the fence when it comes to performing effective compliance examinations."2 A more poignant recognition of the value of such experience came in the nowfamous email from Harry Markopolos, the investment professional who doggedly pursued confessed Ponzi-schemer Bernard Madoff, in which Markopolos observed that the SEC New York Branch Chief to whom he was trying to explain his analysis of Madoff's professed trading strategy did not have "the derivatives or mathematical background to understand the violations."

More regulators with industry experience could help the government overcome weaknesses that have contributed to the financial crisis. Recent U.S. Government Accountability Office (GAO) testimony points to several failings

supervision)."); Harvey L. Pitt, Bringing Financial Services Regulation into the Twenty-First Century, 25 YALE J. ON REG. 315, 321 (2008) ("'R] egulation ... must be rationalized by creating an overarching federal regulatory system that would decrease, if not eliminate, burdens of duplicative, overlapping and conflicting regulation....").

2 The Accountant, Compliance, and Enforcement Staffing Act of 2003: Hearing on H.R. 658 Before the H. Subcomm. on Capital Markets, Insurance and Government Sponsored Enterprises, 108th Cong. 4 (2003) (testimony of James M. McConnell, Executive Director, U.S. Securities and Exchange Commission) [hereinafter McConnell Testimony].

3 E-mail from Harry Markopolos to Jonathan Sokobin (Apr. 2, 2008, 11:13 EST), available at http://online.wsj.com/documents/Madoff_AprilSECdoc_20081217.pdf. 
that hindered the regulatory system, including: (1) regulators' struggle, and often failure, to mitigate the systemic risks posed by global, complex, and interconnected financial conglomerates and to ensure that the institutions themselves managed their risks; (2) the challenge to regulators posed by the increasing prevalence of new and more complex financial products and their associated risks; and (3) regulators' failure to adequately oversee the sale of mortgage products that posed risks to consumers and to the stability of the financial system. ${ }^{4}$ One ingredient that could help address each of these weaknesses is additional industry expertise within the regulatory agencies. As a recent report by the Group of Thirty Working Group on Financial Reform ${ }^{5}$ found:

Regardless of how regulatory agencies are reorganized, prudential supervisors['] ... role requires a renewed emphasis on the complex nature of judgments about the stability of large banking institutions. The caliber, quality, and integrity of people required to meet these challenges points to the need for more substantial efforts to attract, develop, and retain individuals fully capable of engaging senior private sector counterparts. ${ }^{6}$

The benefit of having regulators who understand the companies they regulate cannot be overstated. They are likely to know whom to talk to, which questions to ask, and what databases and documents to examine. Who better to examine and oversee the large, complex, globally active, interconnected financial institutions than people who worked in them, saw their operations from the inside, and perhaps even had some role in constructing them? The complexity and interconnectedness will become less opaque to regulators when they can see the institution through the eyes of insiders. Similarly, the complex structured products and corporate finance transactions can be explained and examined by people who worked on them, marketed and sold them, and perhaps even had a role in creating them. Again, industry players will give regulators a window into these products they may not have had to date.

One silver lining of the financial crisis for the government is that it has left the market flush with skilled risk managers, lawyers, internal auditors, and other professionals from the business world newly willing to work for government wages. The consolidations and general slowdown in the financial industry have led to a significant industry contraction. The result has been massive layoffs and greatly diminished compensation. ${ }^{7}$ Thus, the regulatory

4 See GAO Testimony, supra note 1.

5 The Group of Thirty, established in 1978, is a private, nonprofit, international body composed of very senior representatives of the private and public sectors and academia. The Working Group on Financial Reform was led by Chairman Paul Volcker and Vice Chairmen Tommaso PadoaSchioppa and Arminio Fraga Neto.

6 See G30 REPORT, supra note 1.

7 See William Holstein, Helping 240,000 Find a Future After Wall Street, N.Y. TIMES, Jan. 17,2009 , at B2 (" $[A] t$ the end of 2008, the number was that 240,000 had been laid off on Wall Street in an 18-month period."); Louise Story \& Eric Dash, What Goes Around, N.Y. TimES, Dec. 19, 2008, at B1 ("The normal buzz of money - big money-is all but silenced. While many bankers will still collect sixor even seven-figure bonuses, the average payout for rank-and-file employees will be cut substantially."). 
agencies have a golden opportunity to fill their ranks with the kind of seasoned professionals they ordinarily have difficulty hiring. ${ }^{8}$ The regulators should seize this opportunity to fill their ranks with professionals with experience in the industries they regulate. ${ }^{9}$ While some of these people may return to the private sector once the markets improve, others will likely find themselves at the stage of their career where the stability of a government job is appealing, the private sector has not generated jobs fitting their expertise, or they find public service rewarding.

Concern about allowing the "fox in the chicken coop" is probably overblown with most professionals likely to be appropriately self-critical once in the public sector and properly trained, supervised, and subject to conflict-ofinterest rules. The drive to serve the public good is strong once one is serving in government. Nevertheless, a healthy skepticism is warranted here, especially given the public's view of the "revolving door" between government service and the financial sector. ${ }^{10}$ Training and supervision of new employees is essential. Conflict-of-interest rules governing the post-employment period exist. ${ }^{11}$ If they are inadequate to ensure the public's confidence, they should be enhanced, for example, by placing additional limits on the post-employment period for regulators. ${ }^{12}$

Although many blame Wall Street for the crisis, excluding everyone who could conceivably share some of the blame would leave very few people knowledgeable enough to serve effectively. If one is looking to assess blame, one could ask not only whether Wall Street took on too much risk and leverage and created products that were too complex and opaque, but also whether home buyers purchased houses they could not afford, whether real estate brokers sold houses they should not have, and whether lenders provided financing that

8 See McConnell Testimony, supra note 2 ("The nature of the Commission's work requires that we seek highly skilled individuals who often are at a point in their careers where they have a number of employment options available to them.... We have, time and time again, seen the best applicants for accountant, economist and securities compliance examiner positions snapped up by competitors before the Commission has reached the point in the rigid competitive service hiring process where it can make them an offer.").

9 President Obama has proposed a thirteen percent increase in the SEC's 2010 budget over its 2008 budget. See Press Release, SEC, Statement of Chairman Schapiro on Proposed Budget for SEC (Feb. 26, 2009), available at http://www.sec.gov/news/press/2009/2009-37.htm. While some of this money will be allocated to additional positions within the agency, a portion of the money could be set aside for a recruitment and retention program.

10 See Michael Lewis \& David Einhorn, Op-Ed., The End of the Financial World as We Know $i t$, N.Y. TIMES, Jan. 3, 2009, at WK9 ("The new [SEC] director of risk assessment was no more likely to grasp the risk of Bernard Madoff than the old director of risk assessment because the new guy's thoughts and beliefs were guided by the same incentives: the need to curry favor with the politically influential and the desire to keep sweet the Wall Street elite.").

11 See, e.g., 5 C.F.R. $\S \S 2637.101-2637.216$ (2008) (government-wide post-employment restrictions); 12 C.F.R. §§ 264a.1-6 (2008) (Federal Reserve Bank); 12 C.F.R. § 336.12 (2008) (Federal Deposit Insurance Corporation); 12 C.F.R. $\$ \S 507.1-5$ (2008) (Office of Thrift Supervision); 17 C.F.R. $\S 200.735-8$ (2008) (SEC).

12 See Michael Lewis \& David Einhorn, Op-Ed., How to Repair a Broken Financial World, N.Y. TIMES, Jan. 4, 2009, at WK10 (proposing to "forbid regulators, for some meaningful amount of time after they have left the S.E.C., from accepting high-paying jobs with Wall Street firms."). 
borrowers could afford only if housing prices continued to climb and interest rates stayed low. One could also ask whether providers of mortgages did insufficient underwriting, whether investment bankers created incentives to "feed the beast" in order to continue to generate mortgage-backed securities, whether rating agencies did an inadequate job rating the tranches of the securities created by the investment banks, and whether the regulators themselves adequately oversaw this process, foresaw the risks, and understood the products. If everybody in this chain of blame is deemed ineligible to participate in the solution, there will be few indeed left in a position to serve.

\section{Enough Access}

The regulators must have sustained access to the companies they are regulating. No matter how capable or experienced the personnel employed by the regulatory agency, a regulator is unlikely to be able to obtain information and avert problems and crises without sustained and meaningful access to the regulated companies and their personnel. This is not simply a question of resources, although adequate resources are a necessary condition for regulators to obtain sufficient access. It is also a question of philosophy.

Different financial regulators employ different examination approaches. The SEC conducts four kinds of examinations of companies it regulates: "sweeps" that look at a sample of firms to assess a particular risk, "cause" exams where the staff has reason to believe a violation has occurred, "oversight exams" to evaluate the examinations conducted of the company by a selfregulatory organization, and exams of each firm on a "cycle." 13 Typically, a team from the SEC's Office of Compliance Inspections and Examinations that is assigned to examine one financial institution on one occasion is unlikely to have much overlap with the next team to examine the institution. Even large institutions can go for fairly long stretches of time without seeing examiners, or if they do see a team, the examiners will essentially be starting from scratch.

Bank regulators have a different, and in terms of a model for going forward, more effective, approach. Section 10(d) of the Federal Deposit Insurance Act requires that the federal banking regulators for a large insured depository institution conduct a full-scope, on-site examination of the institution at least once during each twelve-month period. ${ }^{14}$ In practice, bank examiners often have a continuous, or near continuous, presence at the large financial institutions under their jurisdiction. Typically, teams of examiners are assigned to institutions and often examine those institutions multiple times. At its best, this form of regulation involves embedding a team of knowledgeable

13 Examinations by the Securities and Exchange Commission Office of Compliance Inspections and Examinations, Materials from SEC Speaks in 2008 Conference (posted Mar. 20, 2008), available at http://sec.gov/about/offices/ocie/ocieoverview.pdf.

1412 U.S.C. $\S 1820$ (d) (2006). The federal banking regulators consist of the Office of the Comptroller of the Currency, the Federal Reserve Bank, the Office of Thrift Supervision, and the Federal Deposit Insurance Corporation. 
and competent regulators with an identified leader inside a company for a sustained period of time, on a repeat basis. The team learns enough about the company it is examining to make informed judgments about the risks the company is running, the key business decisions it is making, the quality of management, and the strength of internal controls.

There are various factors that can undermine effective examinations even conducted under the best model. Some degree of rotation of regulatory personnel is desirable to avoid "captive regulators," but too frequent rotation prevents the regulators from becoming sufficiently knowledgeable about the institution to really know where to look and what to ask. A proper balance needs to be struck. In addition, as discussed more fully below, the risk of "captive regulators" must be balanced against the risk of overly adversarial examiners who can disincline a company to cooperate. If a company concludes that examiners are "out to get" the company, its personnel may look for ways to minimize cooperation and provide as little information as they can get away with. In the end, adversarial examinations serve neither the company nor the regulator.

One could suggest that recent events have rendered no clear judgment as to which regulatory model actually achieves better results in practice. For every Bear Stearns, Lehman Brothers, and Merrill Lynch that fell principally under the SEC's examination jurisdiction, there was a Citigroup, Wachovia, or Washington Mutual that was the responsibility of bank regulators. If, in the end, the bank regulation model was no more successful in helping the large financial institutions under its jurisdiction skirt the effects of the financial crisis and the bursting of the real estate bubble, what difference does it make which examination model is adopted going forward? The answer is that the access provided by the banking examination model is a necessary but not sufficient condition for effective regulation. Without the right personnel, enough information, and properly organized and forward-thinking regulatory agencies, all the access in the world will not matter. On the other hand, the right people in a well-organized, forward-thinking agency are unlikely to succeed if they do not have adequate and sustained access to the companies they regulate.

A principal rationale for the bank regulatory model has been to protect the federal treasury - that is, insured bank deposits. By proposing to extend this model to at least large financial institutions that may not hold insured bank deposits, another rationale becomes relevant as well-the importance of the institution to the stability of the financial system. To the extent that failure of a large financial institution that does not hold bank deposits can threaten the stability of the financial system, that institution is certainly deserving of the kind of examination attention given to banks, and use of bank regulatory resources for this effort is clearly justified. ${ }^{15}$ To the extent that so many of the

15 See G30 REPORT, supra note 1, at 17 ("The inherent volatility of free and open financial markets and the danger that volatility may occasionally reach crisis proportions threatening economic stability, needs to be recognized in the design of the financial system [and] ... [r]equir[es] [that] non- 
remaining large financial institutions are in the process of converting themselves into bank holding companies or have received substantial infusions of government funds, this issue may be largely moot in any event.

\section{Enough Information}

The regulators must maximize the information they obtain from industry. This maximization will require achieving the proper balance between robust enforcement of the law and the creation of proper incentives for regulated parties.

Enforcement is essential for deterring and punishing serious and unremedied wrongdoing. ${ }^{16}$ At the same time, when regulators are perceived as overly adversarial, companies have a disincentive to turn over information voluntarily when doing so will inevitably result in disciplinary action against them. Most, if not all, regulators acknowledge the wisdom of crediting cooperation and self-reporting of wrongdoing, citing a variety of rationales. ${ }^{17}$ However, the different distribution of resources and organization among financial regulators has resulted in very different approaches to enforcement in practice. The SEC has a proportionally large staff (particularly of lawyers) devoted to enforcement and a tradition as a law enforcement agency. In contrast, the bank regulators, while having enforcement staffs that do bring actions, have more resources proportionally devoted to regulation and examination and less to enforcement. As a result, no matter what is articulated as the philosophy of the agency, communication and cooperation with bank regulators appear to come at substantially less risk of future enforcement action than do communication and cooperation with the SEC.

Achieving a modus vivendi whereby a company that finds problems shares information with a regulator which, in turn, considers forgoing enforcement action against the company if the company itself takes appropriate disciplinary

bank financial institutions that are also judged potentially to be of systemic importance ... be subject to some form of formal prudential regulation and supervision ....").

16 See Mary L. Shapiro, Chairman, SEC, Address to Practising Law Institute's SEC Speaks in 2009 Program (Feb. 6, 2009), available at http://www.sec.gov/news/speech/2009/spch020609 mls.htm ("It is precisely during times like these that we need an SEC that is the investor's advocate-that has the staff, the will and the resources necessary ... to vigorously prosecute those who have broken the law and cheated investors ...."); see also Turmoil in the U.S. Credit Markets: The Genesis of the Current Economic Crisis: Hearing Before the S. Comm. on Banking, Housing and Urban Affairs, 110th Cong. 7 (2008) (statement of Arthur Levitt, Jr., Senior Advisor, The Carlyle Group) ("Enforcement is so important not because the SEC can catch every cheat and prevent every abuse. It's important because it holds people accountable and serves as a powerful deterrent to bad behavior-and is the most powerful tool a regulator has to keep a market functioning.").

17 See, e.g., Report of Investigation Pursuant to Section 21(a) of the Securities Exchange Act of 1934 and Commission Statement on the Relationship of Cooperation to Agency Enforcement Decisions, Exchange Act Release No. 44,969, 76 SEC Docket 220 (Oct. 23, 2001), available at http://www.sec.gov/litigation/investreport/34-44969.htm (known as the "Seaboard Report") ("When businesses seek out, self-report and rectify illegal conduct, and otherwise cooperate with Commission staff, large expenditures of government and shareholder resources can be avoided and investors can benefit more promptly."). 
and remedial action can be an effective way to incentivize a company to be forthcoming with information. Even with a regulatory regime weighted heavily towards enforcement, a regulated company will want to stay on the good side of its regulator. At the same time, where there is no legal obligation to report and where the likelihood of regulatory detection is low, but where the information would be of value to regulators, it is in everyone's interest for a company to communicate with its regulator. The regulatory system should create the proper incentives for this communication to take place. The regulators will rightly be expected to enforce the law vigorously, and by doing so judiciously, they can also keep themselves firmly in the flow of information.

\section{Internal Brain Trust}

The regulators should create an internal brain trust to accumulate information acquired from individual companies and industries and make comparisons between companies and across industries, looking for trends and warning signs. Even with the right people, sufficient access to companies, and a free flow of the right kind of information, regulatory agencies need a central nerve center to process, synthesize, and analyze the information. The people in this nerve center need to be able to engage in the unrestrained, outside-the-box thinking that can overcome conventional wisdom and test implicit assumptions.

Some parts of existing financial regulatory agencies have within their responsibilities certain aspects of this mission. ${ }^{18}$ This function needs to become centralized, and have its status enhanced, its mission clarified and publicized, and its authority clearly established. The GAO has observed:

[N]one of the financial regulators is tasked with assessing the risks posed across the entire financial system by a few institutions or by the collective activities of the industry ... . [N]o one regulator had the necessary scope of oversight to identify the risks to the broader financial system.... Having a single entity responsible for assessing threats to the overall financial system could prevent some of the crises that we have seen in the past. ${ }^{19}$

18 See Commodity Futures Trading Comm'n, Economic Analysis, http://cftc.gov/EconomicAnalysis/index.htm (last visited Mar. 11, 2009) ("The CFTC Office of the Chief Economist conducts research on major economic issues related to the futures and options markets"); Office of the Comptroller of the Currency, Careers at the OCC: OCC Structure and Work Environment, http://www.occ.treas.gov/jobs/info.htm (last visited Apr. 23, 2009) ("[The OCC Office of] Economic \& Policy Analysis... is responsible for managing the agency's economic research and analysis program, providing policy advice on issues relating to the condition of the banking industry and trends in the provision of financial services . . . ."); SEC, Office of Economic Analysis, http:/www.sec.gov/about/economic.shtml (last visited Mar. 11, 2009) ("The Office [of Economic Analysis] engages in research in support of longer-term SEC policy initiatives and plans. This includes research into the causes and consequences of significant developments in the securities markets, in prevailing financial practices among issuer firms, and in SEC policy."); SEC, Office of Risk Assessment, http://www.sec.gov/about/offices/ora.htm (last visited Mar. 11, 2009) ("ORA was formed in 2004 to help the SEC anticipate, identify, and manage risks, focusing on early identification of new or resurgent forms of fraud and illegal or questionable activities. ORA focuses on risk issues across the corporate and financial sector, including issues relevant to corporate disclosure, market operation, sales practices, new product innovation, and many other activities of financial market participants."). 
If there is a consolidated regulator, adequate resources should be provided for this risk assessment function and top talent recruited for it. If there is no consolidated regulator, the brain trust should bring together the personnel in the existing agencies most accustomed to the forward thinking and questioning that will be required. They should be given access to the findings of the examinations of the significant financial institutions. They should be authorized to bring in outside experts and consultants and seek advice and guidance from sources in industry and academia and from abroad. They should meet on a regular basis with an agenda that breaks down the institutional barriers inherent to having separate regulatory agencies and should be directed to engage in the kind of forward-looking strategic thinking that has too often been considered a luxury within government. They should ask the kinds of questions that, in hindsight, one wishes regulators and the industry had asked to more effect over the last few years: if we are in a bubble driven by asset appreciation, what might be the effects when that bubble bursts? How can companies protect themselves now against such effects? What are the greatest risks companies are running? Which companies are outliers or otherwise more vulnerable? Where is there systemic risk?

\section{Rapid Reaction Team}

The regulators should have the regulatory equivalent of a "rapid reaction team"- a team of skilled people prepared and empowered to act quickly in a financial emergency. In addition to their regularly assigned responsibilities in ordinary circumstances, members of the team could be pre-identified to assemble as a group in an emergency and asked to develop systems in advance to address these kinds of crises. The team should draw upon different skill sets - attorneys, economists, examiners, and policymakers-and from personnel from the different financial regulatory agencies. People with experience with recent financial emergencies should play a central role. Treasury itself might be the logical coordinator for this standing team, absent a consolidation of the financial regulatory agencies.

Those designing the regulatory reform need to initiate an effort somewhat akin to a regulatory "disaster recovery" or "emergency preparedness" plan. After $9 / 11$, much thought went into disaster recovery. The corporate world formulated disaster recovery plans under the direction of regulators. Companies built backup data centers and redundant systems and gathered emergency contact information. They designated people to be in certain locations, and designed a command and control structure. Regulators set the priorities and examined companies to make sure plans were in place. Both the companies and their regulators emphasized planning and thinking ahead.

The financial crisis should serve as a comparable wake-up call for regulators to the need for an emergency preparedness plan for financial emergencies. As the GAO has observed, "once firms began to fail [in 2008] 
and the full extent of the financial crisis began to become clear, no formal mechanism existed to... potentially stop or help mitigate the fallout from these events." ${ }^{\text {,20 }}$ These emergencies are now occurring more frequently than terrorist attacks, and the preparedness plan will probably need to be employed on a more frequent basis at least for the near future. If the past year has taught anything, it is to expect the unexpected. When a future Lehman or Citigrouptype crisis arises (or, for that matter, a crisis comparable to the implosion of the hedge fund Long-Term Capital Management in 1998), this pre-identified rapid reaction team should be prepared to engage with the company or fund, communicate with the other arms of government, and act as the information gathering arm and advisors for the key government decision-makers. The team would strive to make the ultimate resolutions of these crises consistent and less improvised.

\section{Conclusion}

Can the Obama Administration effectively regulate the financial sector? Yes, it can. Any unwieldy regulatory bureaucracies created by the Administration as part of its financial reform agenda that lack the attributes outlined above will not play an effective role in preventing or mitigating future financial crises. The Obama campaign ran on a platform of financial regulatory reform as a remedy against future upheavals. To succeed, the new Administration must design an architecture for its new regulatory apparatus that ensures that the right people will have the access, information, structure, and guidance to tackle their daunting job.

20 GAO Testimony, supra note 1, at 13; see also G30 REPORT, supra note 1, at 18 ("Basic crisis resolution procedures and resources should be available to official agencies to deal with instances of institutional failure so severe as to potentially impair system functioning."). 